\title{
(Outo)biografie as teologie
}

Author:
Julian C. Müller ${ }^{1}$
Affiliation:
'Department of Practical
Theology, Faculty of
Theology, University of
Pretoria, South Africa
Note:
Prof. Dr Müller is the Deputy
Dean of the Faculty of
Theology at the University of
Pretoria, South Africa.
Correspondence to:
Julian Müller
Email:
julian.muller@up.ac.za
Postal address:
Faculty of Theology,
Un.doi.org/10.4102/hts.
University of Pretoria,
Lynnwood Road, Hatfield
O083, Pretoria, South Africa
Müller, J.C., 2011 , '(Outo)
biografie as teologie',
HTS Teologiese Studies/
Received: 17 June 2011
Accepted: 21 July 2011
Published: 04 Nov. 2011

C 2011. The Authors. Licensee: AOSIS OpenJournals. This work is licensed under the Creative Commons Attribution License.

\begin{abstract}
(Auto)biography as theology
This article provides a reflection on the relationship between (auto)biography and theology. This reflection is done with reference to, and in honour of the story of Theuns Dreyer. The author positions himself on the theory that the theology develops on a narrative basis and therefore also by way of (auto)biography. The life of a person, in this case a theologian, is regarded as a 'piece of art' and becomes both a reflection of one's theology and a way of constructing a theology. The richness of walking the inbetween land (ecotone) and to combine two contexts (church and academia) in one story is also explored.
\end{abstract}

\section{Inleiding}

Ek en Professor Theuns Dreyer was saam eerstejaarstudente aan TUKS (Universiteit van Pretoria) in 1964. Ongelukkig was die Hervormde en die NG-opleiding op daardie stadium nog in twee afdelings van die Fakulteit Teologie geskei - twee afdelings wat eintlik maar soos twee afsonderlike fakulteite gefunksioneer het. Ons was dus van mekaar bewus, maar het relatief min raakpunte gehad. Gelukkig was die kursus nog detyds gestruktureer in 'n driejarige BA-admissie, waarna die BD-graad gevolg het. Ons het almal saam die eerste BA-deel gehad en dit is waar die Nederduits Gereformeerde- en die Hervormdestudente mekaar redelik goed kon leer ken. Sedert daardie jare het ons twee se paaie in die twee verskillende denominasies, weg van mekaar, maar tog steeds in sigafstand van mekaar, ontwikkel. Ons het albei voortgegaan met studies in Praktiese Teologie en is mettertyd aangestel as hoogleraars in ons vak - Theuns in Afdeling A en ek in Afdeling B. Na die samesmelting van die twee afdelings in 2000 is hy aangestel as hoof van die Hervormde Teologiese Kollege en het in dié hoedanigheid verantwoordelikheid geneem vir die kerkeie deel van die opleiding vir die Nerderduitsch Hervormde Kerk van Afrika (NHKA). Terwyl ek hoof was van die Departement Praktiese Teologie, was dit nodig dat ons goeie kontak behou. Veral in die laaste jare toe die kerklike kontrakte tussen die verskillende kerke en die Universiteit heronderhandel moes word, het ons nader aan mekaar gegroei. Die wedersydse vertroue in mekaar, het ons gehelp om 'n goeie verstandhouding te bou en ons kon ons kollegialiteit met integriteit bevorder. Sedert September 2010 was ek ook bevoorreg om in 'n kantoor te werk wat omtrent reg langs syne op die grondvloer van die Fakulteit Teologie geleë is. Ons paaie het dikwels gekruis.

Juis omdat my en Theuns Dreyer se professionele lewensverhale nogal ineengevleg is, is dit vir my 'n voorreg om hierdie artikel aan hom op te dra. Dit maak ook sin om in 'n artikel soos hierdie te reflekteer op die verband tussen 'n persoonlike verhaal (biografie) en teologiese ontwikkeling. Ek gebruik die artikel vir 'n teoretiese refleksie op die saak van (outo)biografiese teologie met sydelingse verwysings na ons albei se verhale as praktiese teoloë.

\section{Lewensteologie}

Die boek van James McClendon (1974) staan in die tradisie van narratiewe teologie waar godsdienstige idees in storievorm uitgedruk word. Mens sou daarna kon verwys as 'story theology' en hy gebruik ook die term 'theology of life'. McClendon (1974:188-201) identifiseer sewe uitgangspunte ter verduideliking van die verband tussen lewensverhale en teologie. Dit vorm ' $n$ belangrike agtergrond waarteen enige (outo)biografiese teologiese refleksie gedoen moet word. Ek gee dit in my eie woorde weer:

- Die primêre uitgangspunt is dat teologie op 'n narratiewe wyse uitgedruk kan word. Of sterker, dat verhale 'n manier van uitdrukking is wat ideaal geskik is vir teologie.

- Deur verhale word dit moontlik om die 'compelling quality of lives' teologies te verstaan en te begryp wat die betekenis daarvan is.

- Verhale maak dit moontlik om die metafore wat die 'compelling lives' geïnspireer het, te begryp. 
- Sodoende word dit moontlik om die oortuigings wat karakter vorm, te onderskei. Daar moet onderskei word tussen oortuigings en beginsels. Laasgenoemde word bewustelik gevorm, terwyl oortuigings onbewustelik gelewe en uitgeleef word.

- Teologie het tradisioneel outobiografie as waardevolle bron erken (vgl. byvoorbeeld die Konfessies van Augustinus).

- Die sentrum en beginpunt van Christelike teologie is die lewe van Christus.

- Die persoon wie se verhaal vertel word, is altyd ' $n$ karakter binne 'n gemeenskap. So 'n persoon kan alleen verstaan word indien ons ook sy ofhaar deelname aan geloofs- en ander gemeenskappe begryp.

My boek, Om te mag twyfel (2011), het onlangs verskyn en daarin het ek my geloofs- en teologiese reis op 'n outobiografiese basis ontwikkel. Die boek is gebore en het grootliks ontwikkel tydens 'n navorsingsverblyf van twee maande aan die Vrije Universiteit van Amsterdam, waar ek ook die voorreg gehad het om oor die tema van (outo) biografiese teologie te doseer. Die refleksie in hierdie artikel is onder meer deur hierdie ervaringe geïnisieer. Wanneer ek ook na my eie verhaal verwys, probeer ek nie die aandag van Theuns Dreyer na myself verskuif nie. Inteendeel, ek probeer slegs met enkele verwysings na my eie verhaal iets illustreer van die verband tussen biografie en teologie.

Wat gebeur as mens (outo)biografies werk? Stories kom na vore. Ervaringe word ge-storie en in die nadenke daaroor en refleksie daarop, ontstaan nuwe verhale. Teologie word geformuleer en gevorm - nie op argumentatiewe basis nie, maar op 'n narratiewe basis. Natuurlik is verhale ook vol argumente, maar hulle is veral kontekstueel. Argumente wat los van verhale aangebied word, loop die gevaar om a-histories, a-kontekstueel en uiteindelik irrelevant te raak. Nie net irrelevant nie, maar ook nutteloos en magteloos. Want stories is nie alleen ' $n$ manier om ervaringe te beskryf nie, maar ook ' $n$ manier om onsself en ons realiteite te konstrueer en sodoende betekenis aan die ervaringe te gee (Sclater 2003:317). Deur die proses van taling (languaging) vorm ons ons verhale, maar dan vorm daardie verhale weer vir ons tot wat ons word. Dit is ' $n$ nimmereindigende proses van storie en word, word en storie.

Die eerste keer waar ek ervaar het ek word doelbewus uitgedaag om my teologie te storie, was in 'n werkswinkel wat deur Jill Freedman and Gene Combs, van die Family Centre, Evanston, Chicago (skrywers van die boek, Narrative Therapy. The social construction of preferred realities, wat in 1996 verskyn het) aangebied is. Dit was een van hul sogenaamde Level Two Workshops en word gedoen met 'n klein groepie van sowat agt persone. 'n Intensiewe narratiewe proses word gebruik om al die betrokkenes te betrek. Die werkswinkel duur 'n week lank en elke deelnemer kry geleentheid om feitlik 'n volle dag lank die 'kliënt' te wees. Met die fokus net op jou, word jy deur die twee aanbieders gelei om enige ervaring of aspek van jou lewe te vertel en al vertellende te konstrueer.
Toe my beurt aanbreek, het ek gekies om met hulle in gesprek te tree oor die verhouding tussen my teologie en die narratiewe terapeutiese benadering. Die gevolg was dat ek op 'n hoogs professionele wyse deur hulle gelei is om intensief oor my eie teologiese posisie na te dink en dit te vertel. Die gespesialiseerde manier waarop hulle my begelei het in die vertel en dekonstruksie van my teologiese verhaal, was 'n onbeskryflik ryke ervaring. Dit het my vir die eerste keer gehelp om my teologie te eksternaliseer en daarop te reflekteer. Ek kon veral ook ontdek hoedat my teologie eenvoudig deel van my lewenstorie is. Dit was 'n ontdekking van die verhouding tussen outobiografie en teologie, hoewel ek dit toe nog nie so kon verwoord nie.

'n Hele paar jaar later, in 2010, het ek die voorreg gehad om as inwonende navorser vir twee maande aan die Vrije Universiteit van Amsterdam deur te bring. Daar word ek toe gevra om 'n lesing oor Biografie en Teologie te lewer. Sodoende kon ek uit 'n ander hoek opnuut akademies reflekteer op die verhouding tussen 'n persoonlike verhaal (biografie) en teologie. Dit was juis hierdie ervaring wat my verdere vrymoedigheid gegee het om my boek, Om te mag twyfel, te skryf en te publiseer.

\section{'n Netwerk van verbindingslyne}

My blootstelling aan bogenoemde en ander narratiewe prosesse het my gehelp om meer vry te raak van dogma en om die narratiewe benadering ook teologies te omhels. Of, anders gestel, om teologie binne die 'primary modes' (Brueggeman 1989:1) van storie, poësie en liturgie te ontdek. Deel daarvan is die ontdekking dat teologie ook nie los gedink kan word van die self en die verhaal van die self nie. Ons (outo)biografieë of lewensverhale openbaar 'n 'complex matrix of connections' (Sclater 2003:318). Teologie, soos alle aspekte van ons lewensparadigmas, kan alleen verstaan en geformuleer word met verwysing na hierdie matriks. Teologie het te doen met lewe en identiteit. As sodanig is teologie dinamies. Dit is nooit staties nie, maar is tog ook nie sonder kontinuïteit nie, soos wat ' $n$ verhaal nooit klaar vertel is nie.

Sclater (2003:321) verwys na die sogenaamde 'three crucial aspects of narrative as identity' en hierdie 'crucial aspects' wys waarom teologie, die verhaal en identiteit so onafskeidbaar aan mekaar verbonde is:

- Eerstens is daar 'n morele aspek. Om 'n persoonlike storie te vertel is om ' $n$ morele posisie in te neem. Menslike moraliteit het ten diepste 'n narratiewe karakter (vgl. Barbieri 1998).

- Daar is ' $n$ sosiale en kulturele dimensie en daarom is dit interpersoonlik van aard:

To narrate is to assume or imagine an audience but it is also more than that - it is to engage as a self, as an active, interpretive human agent, with others and with the world.

(Sclater 2003:321)

- Deur die proses van verhale te konstrueer (storying) word ons uitgedaag tot verantwoordelikheid. Ons is 
'embodied' menslike wesens en ook ingebed en gebonde aan ons verhale. Aan die ander kant is ons juis deur die vaardigheid van die vertel van ons verhale in staat om ons dade ons eie te maak (vgl. Barbieri 1998:373).

Sclater (2003) verwys verder na subjektiwiteit as 'n 'process of always-becoming':

... it involves the ongoing 'identity work' of a human agent, and is dependent upon what Winnicott (1971) called a 'potential' or 'transitional' space in which aspects of the self are created and transformed in relationships with others and within the matrices of culture.

(Sclater 2003:326)

Hierdie 'transitional space' is 'n sleutelkonsep vir die verstaan van teologie as biografie:

To tell one's story is to occupy such a transitional space ... The story provides an intermediate or transitional area of experience in which the self continually negotiates its position in the world, inscribes itself in relation to the available cultural scripts, integrates past, present and future through acts of remembering and telling.

(Sclater 2003: 327)

My liefde vir die postfundamentele verstaan van teologie is ook voortspruitend uit 'n persoonlike verhaal. In 'n ander artikel (2004) het ek geskryf oor my verbintenis met Prof. Wentzel van Huyssteen van die Princeton Theological Seminary. Die postfundamentele verstaan van teologie het my gebring by 'n breekbare en tog ook veilige ruimte van ekwilibrium, omdat dit die moontlikheid fasiliteer van ' $n$ betekenisvolle verbintenis tussen my lewensverhaal en tradisies van teologiese verstaan. 'n Verbintenis tussen 'n baie plaaslike ('local') en spesifieke konteks en 'n lang tradisie van teologiese verstaan wat ook aan my deur baie geslagte heen oorgedra is. Hierdie verstaan wat 'n nuwe paradigma so verwoord dat dit steeds die tradisie van verstaan integreer, het dit vir my moontlik gemaak om myself van die gekanoniseerde dogmas van die kerk te differensieer en om 'n ekwilibrium in 'n 'always-becoming, dynamic theology' te vind (Müller 2009, 2011b).

Dit is juis hierdie idee om 'n ekwilibrium tussen twee wêrelde te vind en die bedryf van teologie tussen-in wat 'n raakpunt tussen my en Theuns Dreyer se verhale bied.

\section{Die belang van die individuele storie vs die storie van die groep}

Theuns Dreyer is 'n kerkman. Dit is prysenswaardig dat hy 'n akademiese teoloog kon wees en bly en nogtans ook 'n leier en funksionaris van sy kerk. Die gevaar is egter dat juis sy kerklike betrokkenheid so oorheersend kan wees dat sy eie persoonlike verhaal daaragter verdwyn. Dan kry die verhaal van die groep voorrang en word hy met sy eie 'klein' verhaaltjie bloot ' $n$ verlengstuk daarvan.

Die Afrikaanse kerkgemeenskap funksioneer sterk korporatief. Veral in 'n relatief klein kerkgenootskap, soos die NHKA, waarin Dreyer ' $n$ leiersfiguur is, is die korporatiewe kultuur waarskynlik nog meer oorheersend. Dit is een vir almal en almal vir een. Die groep en die groep se belange kry voorkeur. Jacobs (2003) beskryf hierdie proses soos volg:

... many members of the one body, collectively celebrate and enact that (congregation) story, to guide each individual member into paths, into life genres, that harmonize with the great melody of God's redeeming work in His creation.

(Jacobs 2003:30)

Volgens hom is dit juis die uitdaging van ' $n$ narratiewe teologie, naamlik om 'n brug te slaan tussen die kerk se metanarratief en individuele lewensverhale.

Ek is saam met Jacobs (2003:25) enersyds eenstemmig met die proses waarvolgens die individuele verhale ingebed word in die groter verhaal van die groep waarbinne dit juis vertel kan word en waarde kan vind. Aan die ander kant is daar 'n duidelike gevaar, naamlik dat die narratiewe dimensie van individuele gelowiges misken kan word. Jacobs vind dit vreemd omdat een van die primêre bronne wat tot die vernuwing van narratiewe teologie gelei het 'n ander klem gelê het. Hy verwys na die filosoof Alasdair Maclntyre se werk, After Virtue (1981). In daardie teks is hy uitermate besorg oor die 'narrative integrity of a given single life'. Die probleem wat Jacobs sien is dat kerklike teoloë meer besorg is oor 'the narrative coherence (or incoherence) of whole traditions', eerder as dat hulle geïnteresseerd is in 'what makes a human life coherent' (Jacobs 2003:25).

Jacobs (2003:26) skryf verder dat 'if one can pierce through the layers of narcissism and sentimentality', behoort daar 'n duidelike bewustheid te wees dat elkeen van ons 'n unieke persoonlike narratief het: '... one whose essential shape is not always easily discerned.' He verwys ook na die geskrifte van Augustinus en veral waar hy in sy Confessions nadink oor geheue en hoe dit ons in staat stel ' ... to revisit the events of our lives and discern the trajectory that they describe' (2003:29).

Die idee van 'n Festschrift is waarskynlik juis dít, of behoort dit te wees. Dit behoort nie alleen die feestelike viering van 'n lewe van diens aan die akademie te wees nie, maar 'n geleentheid om te herbesoek en om na te dink oor die trajek van 'n persoon se biografie. Deur dit te doen, word beide die persoon oor wie dit gaan en ons ander wat deelneem aan die skryf van die verhaal, tot nuwe verantwoordelikheid en posisieinname uitgedaag. Of soos Adeney (2009:169) dit stel: 'studying biographies helps to create a shift in consciousness that allows more complex theories to become conscious and useful ...'

\section{Die lewe as 'n kunswerk op die grense}

Theuns Dreyer se eie persoonlike verhaal verdien refleksie en dit sal hopelik in hierdie bundel gebeur. Sy verhaal mag nie opgaan en verdamp in die groter verhaal van sy kerk nie.

Wat Ellis en Bochner (1996) sê van die 'nuwe etnografie', sou ek ook graag wou bepleit vir 'n 'nuwe Praktiese Teologie', naamlik: 
It is interested in depth of quality and approaches the lives of people as 'works of art'. It is therefore interested in real persons people with smells, tastes, desires, and thoughts. The implication is that the metaphor best suited for the researcher is that of an artist.

(Ellis \& Bochner 1996:18)

Oor hierdie 'nuwe Praktiese Teologie' het ek in die feesbundel geskryf wat aan Andries van Aarde opgedra is (Müller 2011a:353-357). Die konklusie waartoe ek in daardie artikel gekom het, is ook hier van toepassing en van waarde in 'n poging om 'n lens te voorsien vir refleksie op die lewe en werk van 'n bepaalde praktiese teoloog. Daar het ek betoog dat die klem behoort te val op die unieke aard van elke navorser en gevolglik op die verrassende moontlikhede van die interdissiplinêre proses. Van Huyssteen (2006) skryf hieroor:

$\ldots$ in interdisciplinary dialogue the rather a-contextual terms 'theology and science' should be replaced by focussing our attention on specific theologians, engaging in specific kinds of theologies, who are attempting to enter the interdisciplinary dialogue with very specific scientists, working within specific sciences on clearly defined, shared problems.

(Van Huysteen 2006:151)

Praktiese Teologie wat so benader en beoefen word, vra intellektuele en emosionele buigbaarheid. Veral as ons begryp dat praktiese teologie in die sogenaamde'ecotone' funksioneer. Ecotone (n.d) verwys na Robert Smith en beskryf dit soos volg:

\begin{abstract}
... the ecotone represents a shift in dominance. Ecotones are particularly significant for mobile animals, as they can exploit more than one set of habitats within a short distance. The ecotone contains not only species common to communities on both sides; it may also include a number of highly adaptable species that tend to colonize such transitional areas.
\end{abstract}

(Ecotone n.d.)

Die 'ecotone' is ' $\mathrm{n}$ kragtige metafoor vir die verstaan van Praktiese Teologie as 'n postfundamentele onderneming. Die kwesbare publieke ruimte wat deur die interdissiplinêre dialoog geskep word is die praktiese teoloog se 'ecotone'. In hierdie tussen-in gebied is daar ' $n$ verskeidenheid van narratiewe wat ' $n$ rol speel en wat deur die vaardige praktiese teoloog in respek gebring kan word.

Die kwesbaarheid, maar juis daarom die krag van Theuns Dreyer se werk as praktiese teoloog, is dat hy in die 'ecotone' tussen die twee habitatte van kerk en akademie sy werk en lewensruim gevind het. Hierdie tussenruimte sal miskien nie gewoonlik 'n interdissiplinêre tussenruimte genoem word nie, maar na my mening sou dit korrek wees om dit op dieselfde basis te beoordeel. Die ruimte van die kerk en dié van die akademie verteenwoordig inderdaad twee dissiplines, of ten minste twee tale. In daardie ruimte het die kerklike teoloog met 'n diversiteit van narratiewe te make. Dit wat hierbo geformuleer is, geld inderdaad van hom of haar: 'In and through these narratives more than one set of habitats are visited and re-visited.' Hierdie rol van die kerklike teoloog en die kwesbaarheid wat dit meebring, word gewoonlik nie besef en erken nie. Van sulke teoloë word eenvoudig verwag om ewe gemaklik in albei wêrelde te funksioneer, sonder enige erkenning van die spanning wat dit meebring nie. Dit vra ook besondere vaardighede om binne die 'ecotone' tussen kerk en teologie te funksioneer. Soos hierbo gestel: 'To practice practical theology within this line of thought, requires intellectual and emotional flexibility.'

Na my oordeel het Theuns Dreyer op 'n besondere manier deur sy loopbaan daarin geslaag om hierdie intellektuele en emosionele buigbaarheid te bemeester. Die afgelope aantal jare veral, was tye van storm en drang in die NHKA. Die kerk moes haarself ten einde laaste, soos die ander Afrikaanse kerke, herposisioneer ten opsigte van die ideologie van apartheid en die gepaardgaande betrokkenheid-al-dan-nie by die internasionale ekumeniese liggame. Die besluite wat geneem is het gevra vir groot wysheid en het nie sonder spanning gebeur nie. Theuns moes leiding gee in terme van beide die kerklike en die akademiese 'tale'. Na my mening het hy dit met waardigheid en bekwaamheid gedoen. Die spanning is nog nie verby nie en daar word nog gesoek na die 'wide reflective equilibrium'. Hopelik sal die kerk by die buitengewone Algemene Kerkvergadering in Oktober 2011 daarin slaag om hierdie reflektiewe ekwilibrium te vind en daar sal sekerlik ook na Theuns Dreyer opgesien word om dit te help bewerkstellig.

\section{Die betekenis van biografiese refleksie vir teologie en kerk}

My betoog in hierdie artikel is dat teologie eintlik net op 'n (outo)biografiese basis beskryf en gevorm kan word. In die lig daarvan dat dit in die artikel gaan oor die lewensverhaal van 'n kerkman, sou dit ook sin maak om te reflekteer op die vraag wat die betekenis en effek van so 'n benadering op die kerk sou kon hê? Anders gestel: Is hierdie besinning net 'n teoreties-akademiese spel, of kan dit' $n$ betekenisvolle bydrae tot kerklike vernuwing lewer?

Hier laat ek my deur Adeney (2009:160-165) lei wat gereflekteer het op die betekenis van die biografieë van sendelinge op missionêre teorie en praktyk. Na my mening is dit van toepassing op die algemene bedieningspraktyk. Hy sê (in my eie woorde weergegee):

- Eerstens help hierdie benadering om diversiteit te vier, want deur die diverse verhale van verskillende mense word dit algaande duidelik hoedat daar 'n verskeidenheid van manifestasies van die bediening is.

- Verskillende teologieë vir verskillende kontekste. Die spesifieke sosiale kontekste het nie alleen die lewensverhale beïnvloed nie, maar ook die teologieë wat daaruit ontwikkel het.

- Die ontdekking van teologieë in die praktyk. Die ryke en diverse ervaringe van sendelinge, dwing tot ' $n$ '... look beyond their own ideas of mission theology'.

- Herkenning van die kompleksiteit van die verskillende (missionêre) teologieë. Wanneer die verhale van die verskillende sendelinge ernstig opgeneem word, word dit algaande duideliker dat dit wat op die oppervlakte na eenvoudige teorieë en optrede mag lyk, inderwaarheid heel kompleks en gesofistikeerd is. 
- Begryp die eenvoud van die evangelie. Waar die liefde van Christus sentraal staan, lei dit tot 'n vereenvoudiging van idees en optrede.

- Identiteit en betekenis word verhelder:

Missionary biographies disclose ways of knowing and being in the world that have implications for who we are and our purpose for existence. We start off by seeing the world's brokenness through the eyes of someone else - someone who has been sent by God to a particular place to bring life and healing.

(Adeney 2009:163)

- Heelheid en 'n transsendente teenwoordigheid. Al die ideale van die sendelinge dra die visie van harmonie, versorging en vervulling.

- Voortdurende vernuwing van die Christelike visie. In die lig van ander verhale word ons genoop tot nuwe refleksie op ons eie verstaan van die evangelie.

Wanneer die lewens en werk van bepaalde individue in die kerklik-teologiese bediening tot verhaal gebring word, word al die bogenoemde waar. Daar groei nie net 'n besef van die feit dat elke lewe 'n kunswerk op sigself is nie, maar ook 'n nuwe kritiese refleksie op die konteks waarbinne die bepaalde individu se storie as deel van die geheel, maar ook selfstandig ontwikkel het. Biografiese teologie maak die moontlikhede oop vir ' $n$ nuwe, vars kyk op tradisies van interpretasie, want dit is alleen vanuit die perspektief van outentieke verhale dat ons tot ' $n$ herinterpretasie kom. Mag hierdie feesbundel wat op Theuns Dreyer fokus, juis so 'n herinterpretasie van sy lewe én die konteks waarbinne hy gewerk het, bevorder.

\section{Erkenning}

Opgedra aan Prof. Dr Theuns F.J. Dreyer - vriend, kollega, mentor.

\section{Mededingende belange}

Die outeur verklaar dat hy geen finansiële of persoonlike verbintenis het met enige party wat hom nadelig kon beïnvloed in die skryf van hierdie artikel.

\section{Literatuurverwysings}

Adeney, F.S., 2009, 'Why Biography? Contributions of Narrative Studies to Mission: Theology and Mission Theory', Mission Studies 26, 153-172, viewed n.d., from http://dx.doi.org/10.1163/016897809X12548912398758

Barbieri, W.A. Jr, 1998, 'Ethics and the Narrated Life', The Journal of Religion 78(3), 361-386.

Brueggemann, W., 1989, Finally Comes the Poet: Daring speech for proclamation, Fortress Press, Minneapolis, MN.

Ecotone, n.d., Ecotone, viewed 25 March 2010, from http://en.wikipedia.org/wiki/ Ecotone

Ellis, C. \& Bochner, A.P. (eds.), 1996, Composing Ethnography: Alternative forms of qualitative writing, Sage Publications, Walnut Creek, London, New Delhi.

Jacobs, A., 2003, 'What narrative theology forgot', First things, August/September, $25-30$.

McClendon, J.W. Jr, 1974, Biography as theology: How life stories can remake today's theology, Abingdon Press, Nashville, TN.

Müller, J.C., 2004, 'HIV/AIDS, Practical Theology, and Postfoudationalism: The emergence of a new story', Hervormde Teologiese Studies 60(1/2), 293-306. (Geyser gedenkuitgawe.)

Müller, J.C., 2009, 'Tussen-in en duskant geloof', in By se Bedkassieboek, pp. 136-145, Nasionale Boekhandel, Kaapstad.

Müller, J.C., 2011a, 'Postfoundational practical theology for a time of transition', HTS Teologiese Studies/Theological Studies 67(1), Art. \#837, 5 pages. http://dx.doi. org/10.4102/hts.v67i1.837

Müller, J., 2011b, Om te mag twyfel, Tafelberg, Kaapstad.

Sclater, S.D., 2003, 'What is the Subject?', Narrative Inquiry, 13(2), 317-330.

Van Huyssteen, J.W., 2006, Alone in the world? Human uniqueness in science and theology: The Gifford Lectures, Eerdmans Publishing Co., Grand Rapids, MI. 